\title{
Effect of a Rehabilitation Program on the Quality of Life of Patients with
}

\section{Lower Limb Amputation}

\author{
Emad Abd El Gawad Ali Rabie, Assistant Lecturer \\ Medical Surgical Nursing, Faculty of Nursing, Alexandria University \\ Yousria Mohamed Salem, Professor \\ Medical Surgical Nursing, Faculty of Nursing, Alexandria University \\ Maha Adel Salem, Professor \\ Medical Surgical Nursing, Faculty of Nursing, Alexandria University \\ Rasha Ali Yakout, Assistant Professor \\ Medical Surgical Nursing, Faculty of Nursing, Alexandria University \\ Wael El Sayed Shaalan, Assistant Professor \\ Vascular Surgery, Faculty of Medicine, Alexandria University
}

\begin{abstract}
Lower limb amputation (LLA) is usually performed as a life saving procedure to remove all infected, pathologic, or ischemic tissue. Irrespective of the cause of LLA, it has a significant and dramatic change in a person's life which has an effect on quality of life of patients due to the physical activity limitations immediately after amputation and long-term implications in different aspects of life. Objective: Determine the effect of a rehabilitation program on the quality of life for patients with lower limb amputation. Setting: This study was conducted in Surgical Units and Vascular Unit, Department of Surgery, Alexandria Main University and Alexandria Vascular Center (AVC). Subjects: The study subjects were included 50 adult patients with unilateral major LLA, able to communicate effectively and agreed to participate in the study. Tools: Two tools were used for data collection: Preoperative and Postoperative Lower Limb Amputation Assessment Tool and Short Form 36 (SF-36) Health Survey Questionnaire. Results: The study showed that patients in the study group who received the rehabilitation program had higher scores of SF- 36 health domains than those in the control group who received routine hospital care. In addition, there was a statistical significant difference between the two groups in relation to overall quality of life. Conclusion: It can be concluded that mean scores of SF- 36 health domains improved significantly in the study group compared to control group after applying the rehabilitation program. Recommendations: The rehabilitation program should be considered as an integral part in the hospital routine care of patients with LLA.
\end{abstract}

Keywords: Lower limb amputation; Rehabilitation program; Quality of life.

\section{Introduction}

Lower limb amputations are one of the oldest surgical procedures performed in the surgical field $^{(1,2)}$. Despite, advances in preventive care, medical treatment and peripheral revascularization procedures, in some cases, lower limb amputation remains the best option for ending ongoing pain, hospitalization, infection, ischemia, and enabling a person to live ${ }^{(3)}$. whole or part of a limb by cutting through bone or joint. A major lower limb amputation is one that is performed proximal to the ankle ${ }^{(4)}$. Moreover, amputation becomes necessary as a result of trauma, tumors and congenital deformities while, vascular diseases and diabetes are generally the main reasons for amputations $^{(5)}$.

The goals of amputation include elimination of all infected, necrotic, and 
painful tissue; have a wound to heal successfully; and have a functional stump that can accommodate prosthesis. Avoidance of repeated amputations and provision of uncomplicated healing of operative site are crucial for the patient's optimal recovery and best functional rehabilitation or palliation $^{(6)}$.

According to more recent statistics of Amputee Coalition 2016, there are around 2 million people living with limb loss in the United States, and an estimated 185,000 amputations are performed annually, $54 \%$ of amputations are due to complications of diabetes and peripheral arterial disease. Costs of lower-limb amputation procedures accounted for nearly $\$ 7.9$ billion $^{(7)}$. In Egypt, the last prevalence of major diabetic foot amputation is approximately $1 \%$ of all diabetic patients ${ }^{(8)}$.

Lower limb amputations have a high impact on patients' quality of life and are a major burden on national health care systems $^{(9)}$. It is associated with significant morbidity, mortality and healthcare costs ${ }^{(10)}$. Irrespective of the cause of LLA, it has a significant and dramatic change in a patient's life which has an effect on quality of life due to the physical activity limitations immediately after amputation and long-term implications in different aspects of life $\mathrm{e}^{(11,12)}$. Loss of a body part and body image change can lead to loss of confidence; loss of function and lifestyle; loss of role, income and status, loss of independence and control $^{(13)}$. In addition, amputation may affect psychological well-being, resulting in depression, anxiety and social discomfort ${ }^{(14)}$.

Limb loss is a life challenging experience and requires a holistic approach to restore patients physically, psychologically, and spiritually ${ }^{(15)}$. Amputation is an opportunity to reestablish or enhance a patient's functional level and facilitate a return to near-normal locomotion $^{(16)}$. Rehabilitation helps to achieve the maximum possible physical, emotional, social, vocational and financial independency of patients with lower limb amputation and maximum efficiency in all aspects of life ${ }^{(17)}$.

The nurse as a member of the rehabilitation team has a various roles in the rehabilitation process after LLA. The nurse acts as a caregiver, educator, counselor, patient advocator, case manager, and consultant $^{(18)}$. Therapy programs for strengthening range of motion exercises, correct positioning of the residual limb, ambulation with gait aids, relaxation techniques, and resuming activities of daily living (ADLs) should be started as soon as medically appropriate ${ }^{(19)}$. Moreover, stump care, skin care, prosthetic management, donning and doffing of the prosthesis and residual limb wrapping comprise patient education of limb management after surgery $^{(20)}$.

Amputation should not be viewed as a failure of treatment but rather as the first step toward a patient's return to a more comfortable and productive life ${ }^{(21)}$. In this regard, the present study aimed to determine the effect of a rehabilitation program on the quality of life for patients with lower limb amputation.

\section{Aim of the Study}

This study aims to determine the effect of a rehabilitation program on the quality of life for patients with lower limb amputation.

\section{Research Hypothesis}

Patients with lower limb amputation who receive a rehabilitation program exhibit a higher quality of life scores than those who do not receive.

\section{Materials and Method}

\section{Materials}

Design: A quasi experimental research design was utilized in this study.

Setting: The study was conducted in two settings in Alexandria. The first setting was the Surgical Units (Surgical Oncology Unit, Gastrointestinal Surgery Unit, Colorectal Surgery Unit, Head, Neck and Endocrine 
Surgery Unit, and Hepatobiliary and Pancreatic Surgery Unit. The total bed number of these units are 175 beds, each unit receives patients with lower limb amputation due to trauma according to its emergency day) and Vascular Unit, Department of Surgery, Alexandria Main University Hospital, it includes 34 beds. The second setting was Alexandria Vascular Center (AVC) which contains 27 beds. It is private center at Smouha district specialized in the management of patients with peripheral vascular problems and diabetic foot.

Subjects: The study subjects comprised a convenience sample of 50 adult patients undergoing lower limb amputation who were admitted to the previously mentioned settings. They were randomly recruited into 2 groups, group one (control group) and group two (study group), 25 patients for each group. The study subjects were selected according to the following criteria: age: 20 60 years old, first experience to lower limb amputation, unilateral major amputation (below knee amputation, knee disarticulation and above knee amputation, alert, able to communicate and agreed to participate in the current study.

Tools: Data of the present study were collected by using the following tools:

Tool I: Preoperative and Postoperative Lower Limb Amputation Assessment $\underline{\text { Tool }}$

This tool was developed by Fathy $(2014)^{(22)}$ to assess patient status in the preoperative and postoperative phases. It was adapted by the researcher and certain modifications were done. This tool comprised two main parts:

\section{Part I: Preoperative patient assessment:}

This part included the following items:

a. Patients' profile: Patient's name, age, sex, level of education, marital status, occupation, income from patient point of view, telephone number, and address. b. Medical data: Date and time of admission \& discharge, medical diagnosis, affected limb, associated medical diseases, history of previous amputation, level of amputation, cause of amputation, prescribed medications, preoperative patient preparation (informed consent and preoperative anesthesia assessment) and date of operation

\section{c. Assessment of patient's physical} status:

1. General physical assessment: Vital signs, anthropometric assessment, mobility and activity.

2. Lower limbs (intact and affected lower limb) assessment: Lower limb circumference in centimeter at mid-thigh, neurological status and vascular status.

\section{Part II: Postoperative patient assessment:}

This part included the following items:

a. Pain assessment: Occurrence of stump pain and phantom pain, character, duration, pain intensity, radiation, relieving \& aggravating factors. Visual analogue scale (VAS) was used to assess intensity of pain. It is a straight line from zero to ten corresponding to patients' responses to pain experience where 0 is no pain and 10 is worst possible pain ${ }^{(23)}$.

\section{b. Wound healing observation} checklist assessment includes observation of wound healing criteria; as regards type of wound, bleeding, exudates amount, wound edges, skin color surrounding wound, swelling surrounding wound, drain discharge, type of dressing as well as antiseptic solutions. It was expressed on three points and five points Likert scale. The total score value of patient's wound observations ranges between 7-30. 
The lower the score the higher indicator for wound healing as follows: $7-14$ is considered completely healed wound, 15-22 is considered incompletely healed wound and 23-30 is considered poor healed wound.

Tool II: Short Form 36 (SF-36) Health Survey Questionnaire

The SF-36 was developed by Ware (1990). It is a set of generic, coherent, and easily administered quality of life measures $^{(24)}$. Version 2 of the SF-36 was developed in 1996, and updated in $2004^{(25)}$. It was used to assess quality of life (QOL) for amputee patients and was adopted by the researcher. It was already translated into Arabic and was consisted of 36 questions (items) measuring physical and mental health status in relation to eight health concepts. These eight health concepts or domains include physical functioning, role limitations due to physical health problems bodily pain, general health perceptions which form physical health (physical component summary); and vitality, social functioning, mental health (emotional wellbeing), role limitations due to emotional problems which represents mental health (mental component summary).

The values of each item are computed on a scale from 0 (worst possible health status or QOL) to 100 (best possible health status or QOL) then items in the same scale or dimension are averaged together to create the 8 scales scores. The score of each item and each scale, as well as the final global score of the SF-36 range between 0 and 100, indicating that the lower the score the less functioning and well-being and the higher the score the more functioning and wellbeing.

\section{Method}

- An official permission to carry out the study was obtained from the hospitals directors, head of surgical departments and head of Vascular Unit at the selected settings, after explanation of the aim of the study.

- Tool I (Preoperative and postoperative lower limb amputation assessment tool) was adapted by the researcher to assess patient status in the preoperative and postoperative phases and necessary modifications were done while, Tool II (Short form 36 health survey questionnaire) was adopted by the researcher to assess QOL after lower limb amputation.

- Tool I was tested for content validity by 5 experts in the field of Medical Surgical Nursing, Faculty of Nursing Alexandria University to assure the content validity, completeness and clarity of items. Comments and suggestions of the jury were considered and necessary modifications, correction and clarifying of the items were done accordingly.

- The reliability of tool I was measured by Cronbach's alpha test and was equal 0.911 that indicated high reliability of the tool.

- The pilot study was conducted on $10 \%$ of the sample (5 patients) to assess clarity, feasibility and applicability of the study tools and no modifications were done accordingly. The pilot sample was excluded from the study subjects.

- Participants meeting the inclusion criteria were selected and randomly divided into two equal groups (control group and study group). Group one (control group) received the routine hospital care as positioning, dressing and medications. While, Group two (study group) received the rehabilitation program.

- The period of data collection was about 14 Months from February 2018 to April 2019. The study was carried out on four phase: 
I. Assessment phase: Initial assessment of all patients before operation (control and study group) was carried out before beginning of implementation of the rehabilitation program using part I (preoperative patient assessment) of tool I at the preoperative day. Patient was informed that the researcher will meet him, the first postoperative day, the second postoperative day, four weeks and three months after patient's discharge.

\section{Planning phase:}

- Based on the data collected from the assessment phase and review of related literature $(26,27,28,29,30)$, the nursing rehabilitation program goals, priorities, contents, and expected outcomes were developed by the researcher according to the individual needs and problems.

- Teaching strategies included the following: interactive discussion \& range of motion and isometric exercises for the upper and lower limbs demonstration and redemonstration.

- Handout booklet: It was developed by the researcher based on review of the recent related literature $(26,27,28,29,30)$. It was given to every patient in the study group for more illustration of the rehabilitation program contents.

- The contents of the handout booklet covered the following areas: definition and indications of LLA, levels of LLA, postoperative complications, adjustment to amputation, postoperative pain management, phantom limb pain management, proper stump positioning for prevention of muscle contracture, skin care, safety consideration for prevention of fall, wound dressing, wrapping or bandaging of the stump, stump massage, preparation of the stump to tolerate touch and pressure, transfers, mobility, exercise (types, frequency \&duration), care of the remaining healthy limb, information about use of prosthesis, parts of prosthesis, donning and doffing of the prosthesis, training to use the lower limb prosthesis, managing prosthetic socks, gait training with using assistive devices, care of the prosthesis and follow up instructions about monitoring of blood pressure, blood glucose level, serum lipids profile, stump examination and care .

III. Implementation phase (rehabilitation program sessions): The rehabilitation program was implemented individually for each patient in the study group from the above mentioned setting in four sessions. The first session was carried out during the assessment phase the morning or evening of the day before surgery and the second session was carried out in the first day after surgery, the third session was carried out in the second day after surgery while the fourth session was carried out 4 weeks after patient's discharge after amputation for ensuring complete stump healing.

\section{Evaluation phase:}

- The postoperative patient's assessment to assess pain and wound healing during hospital stay and continued in follow up visits up to 4 weeks by using tool I; part II Postoperative patient assessment.

- After one month, and 3 months postoperatively, the quality of life for patients with lower limb amputation was evaluated using tool III. In addition, tool II was used to assess mobility of patients after 3 months postoperatively.

- Comparison of results between study group and control group was done.

\section{Ethical considerations:}

For each included patient the following issues were considered: informed consent was obtained after explanation of the aim of the study, keeping his privacy and assuring 
confidentiality of his data as well as, the right to withdraw at any time during this study was respected and accepted.

\section{Statistical Analysis}

Data were fed to the computer and analyzed using IBM SPSS software package version 20.0. Qualitative data were described using number and percent. Quantitative data were described using minimum and maximum, mean and standard deviation. Significance of the obtained results was judged at the $5 \%$ level.

Comparison between the control and study groups regarding categorical variables was tested using Chi-square test. When more than $20 \%$ of the cells have expected count less than 5, correction for chi-square was conducted using Fisher's Exact test or Monte Carlo correction. For normally distributed quantitative variables, comparison between the control and study groups was analyzed using Student t-test. Paired t-test was used for normally distributed quantitative variables, to compare between two periods.

\section{Results}

Table (1) presents distribution of patients in both control and study groups according to their socio-demographic data. In relation to patients' age, it was found that, the most common age was 50 years to less than 60 years in $(60 \% \& 48 \%)$ respectively of patients in the control and study groups. Regarding to sex, it can be noticed that more than half of patients in the control and study groups were male $(64 \%$ \& 60\%) respectively.

This table also clarifies that, more than one quarter $28 \%$ of patients in the control group were illiterate while, an equal percentage $24 \%$ of patients in the study group had secondary level of education and university education. Most of patients in the control and study groups were married (84\% $\& 72 \%$ ) respectively. Regarding occupation and income, the table revealed that, $52 \%$ of the control group had manual occupation while $44 \%$ of the study group were employee, and more than half $60 \%$ of them in both control and study groups their income was not enough from their point of view. No statistical significant differences were found between the control and study groups as regards to socio-demographic data.

Table (2) shows distribution of patients in the control and study groups according to medical data. In relation to medical diagnosis, more than half of patients in the control and study groups had diabetic foot infection $(64 \%$ \& 52\%) respectively. As regards associated medical disease, $(64 \%$ and $52 \%$ ) respectively of patients in the control and study groups had diabetes mellitus.

The table also revealed that, all patients of the control and study groups did not have any previous history of lower limb amputation and $52 \%$ of them in both the control and study groups had right lower limb amputation. In relation to the cause of amputation, this table showed that, diabetes mellitus was the primary cause of amputation in more than half of patients $(64 \% \& 52 \%)$ respectively in the control and study groups.

Regarding level of amputation, (56\% \& $72 \%$ ) respectively of patients in the control group had below knee amputation. Regarding median hospital stay, it was 6 days in the control group, while median hospital stay of the study group was only 4 days. A significant statistical difference was found between the control and study groups with $P$ value equal 0.007 regarding length of hospital stay while, no statistical significant differences were found between the control and study groups related to other medical data.

Table (3) illustrates postoperative pain assessment of patients in the control and study groups during hospitalization and after discharge (follow up weeks). In relation to incidence of postoperative stump pain, all patients in the control and study groups complained from stump pain during 
hospitalization while, $(96 \%$ \& $88 \%)$ respectively of patients in the control and study groups had stump pain at the second postoperative follow up week and $(72 \%$ \& $60 \%$ ) respectively of patients in the control and study groups had stump pain at the fourth postoperative follow up week. Regarding incidence of phantom pain, all patients in the control and study groups did not complain from phantom pain during hospitalization and follow up weeks.

Concerning stump pain intensity, (40\% \& $48 \%$ ) respectively of patients in the control and study groups had moderate degree of pain during hospitalization however, at the second postoperative follow up week, $44 \%$ of patients in the control group had moderate degree of pain and $70 \%$ of patients in the study group had mild degree of pain. Furthermore, at the fourth postoperative follow up week, $36 \%$ of patients in the control group had moderate degree of pain and $52 \%$ of patients in the study group had mild degree of pain. Furthermore, there was a statistical significant difference between the control and study groups in relation to intensity of pain during follow up weeks.

Table (4) presents postoperative assessment of wound healing of patients in the control and study groups during hospitalization and after discharge (follow up weeks). In relation to stump healing, it can be noticed that, $60 \%$ of patients in the control group had incomplete wound healing while $56 \%$ of patients in the study group had complete wound healing at the first postoperative follow up week. At the second postoperative follow up week $(52 \% \& 80 \%)$ respectively of patients in the control and study groups had complete wound healing. In addition, at the third postoperative follow up week $(60 \% \& 88 \%)$ respectively of patients in the control and study groups had complete wound healing. Also, more than half $64 \%$ of patients in the control group and the majority $92 \%$ of patients in the study group had complete wound healing at the fourth postoperative follow up week. In addition, there was a statistical significant difference between the control and study groups during the second, third and fourth weeks of postoperative follow up period with $P$ values equal $(0.037,0.024$ and 0.017$)$ respectively.

Table (5) illustrates comparison between patients in the control and study groups according to quality of life domains. Regarding the eight quality of life domains, physical component summary, mental component summary and overall quality of life, patients in the study group had higher mean scores than those of the control group. In addition, there was a statistical significant difference between the control and study groups after one month of LLA regarding quality of life domains except role limitations due to physical health domain, role limitations due to emotional problems domain and social functioning domain. However, there was a statistical significant difference between the control and study groups after three months of LLA regarding all quality of life domains.

\section{Discussion}

Amputation is considered as triple insult, as it brings loss of function, loss of sensation, and loss or change of body image. This dramatic change has an effect on the quality of life of the individual due to the physical activity limitations immediately after amputation as well as has longer-term implications in varied facets of $\operatorname{life}^{(12)}$. Extensive and evolving threats and challenges to physical, psychological and social functioning face patients after amputation $^{(31)}$.

Successful rehabilitation for patients with LLA encompasses all the processes aiming not just at treating the impairment or giving patient a prosthesis, but allowing the patient's return to their highest level of activity performance, function, and ultimately participation and return of quality of life ${ }^{(32)}$. Therefore, the present study was carried out to determine the effect of a 
rehabilitation program on the quality of life for patients with lower limb amputation.

The results of the current study revealed that, in relation to patients' age, most of patients in the control group and almost half of patients in the study group were between 50-60 years old. This finding agrees with Mohammed et al. (2014) ${ }^{(11)}$ who conducted study about quality of life among Egyptian patients with upper and lower limb amputation: sex differences and found that more than half of female patients and about two-fifths of male patients were in age group ranged from fifty to less than sixty years. It could be due to chronic macrovascular and microvascular complications of diabetes as diabetes mellitus and peripheral vascular disease are the main causes of lower limb amputation in the current study.

Concerning sex, the findings showed that more than half of patients in both control and study groups were male. These findings are in line with Sansosti et al. $(2017)^{(33)}$ who found that more than half of patients with unilateral major lower limb amputation were male. It might be due to men are more reluctant than women to seek medical help when they are ill and they engage in risk-taking activities that can seriously threaten their well-being and life.

Also the results showed that, most patients in the control and study groups were married. Married patients might receive more psychological and social support from their families, in addition to availability of caregiver which influences patients' adherence to treatment and follow up visits. These findings agree with El Sebaee and Mohamed (2011) ${ }^{(34)}$ who studied stressors and positive coping strategies in patients with new limb amputation and found that almost three quarters of them were married.

In relation to the cause of amputation, this study represented that diabetes mellitus was the primary cause of amputation in more than half of patients in the control and study groups. This finding is in accordance with Rollands et al. $(2017)^{(35)}$ who found that complications of diabetes mellitus were the most common indication for major limb amputations in almost two-fifths of patients.

The present study also reflected that, more than half of patients in the control and study groups had diabetes mellitus. This finding agrees with Al-Thani (2018) ${ }^{(36)}$ who found that, two thirds of patients with upper and lower limb amputation had diabetes mellitus. Regarding level of amputation, more than half of patients in the control group and more than two thirds of patients in the study group had below knee amputation. This finding agrees with Frederiks (2013) ${ }^{(37)}$ who found that, the most common level of lower limb amputation was below knee amputation.

Nurses have an important role in pain management because they have more contact with patients who are experiencing pain than any other healthcare professional (38). The present study revealed a statistical significant difference between the control and study groups regarding the intensity of stump pain as more than half of patients in the study group had mild degree of pain while more than one third of the control group had moderate degree of pain at $4^{\text {th }}$ week of postoperative follow up period. These findings are consistent with Horne $(2014)^{(39)}$ who found a statistically significant reduction in pain intensity in patients with LLA after application of desensitization intervention that includes massage and tapping of the stump during the acute hospitalization phase after surgery. It could be due to nursing interventions introduced to the study group related to assessment of pain, pain management, psychological support, stump massage and management of postsurgical edema which stretches the surgical wound and nerve endings leading to stump pain.

Successful healing of the residual limb is an important step in the recovery process after amputation. The nurse has an important role in effective postoperative dressing management which can reduce residual limb pain, provide protection from injury, prevent 
edema and promote residual limb shaping, as well as maintain range of motion ${ }^{(40)}$. The findings in the present study revealed a statistical significant difference in favor of the study group between both groups during the second to fourth week of postoperative follow up period as the majority of patients in the study group and more than half of patients in the control group had completely healed wound at $4^{\text {th }}$ week of postoperative follow up period. It is in accordance with Fathy $(2014)^{(22)}$ who found a statistical significant difference between the control and study groups during the second to the six week of postoperative follow up period as the majority of patients in the study group had completely healed stump compared to more than one third of patients in the control group at the $4^{\text {th }}$ week of postoperative follow up period.

These findings could be justified by health educations given to the study group about monitoring of blood glucose level, therapeutic diet, medication and follow-up schedule as hyperglycemia decreases oxygen delivery to the tissues which negatively affects macrophage mobility and growth of granulation tissue during wound healing. Also, effective wound dressing, stump care, prevention of complications and patients' compliance with the therapeutic regimen in the study group results in improved wound healing.

Lower limb amputation adversely affects quality of life, particularly the physical health, with consequential difficulty in work and usual activities ${ }^{(41)}$. Regarding physical functioning, the present study reflected that, increased mean scores of physical functioning in the study group more than control group and a statistical significant difference was found between the control and study groups after one month and three months of LLA. This finding is in line with AlSofyani et al. $(2016)^{(42)}$ who conducted a study about impact of rehabilitation programs on dependency and functional performance of patients with major lower limb amputations and found that overall dependency and functional performance were significantly increased in those patients following implementation of the physical rehabilitation programs.

This result could be justified by patients in the study group received effective wound management, correct positioning of the stump, edema control, pain management, exercise programs including range of motion and isometric exercises, early ambulation with assistive devices, relaxation techniques, and encouragement of early participation in activities of daily living (ADLs) when medically appropriate that leads to improve physical functioning.

As regards role limitations due to physical problems, the results of this study showed that, increased mean scores of role limitations due to physical problems in the study group more than the control group and a statistical significant difference was found between the control and study groups after three months of LLA. It might be due to patients in the control group had reduced mobility which affected their ability to perform daily tasks and activities of daily living. However, there was no statistical significant difference between the two groups after one month of LLA because of ambulation with assistive devices requires more energy and effort, presence of surgical wound and stump pain during the first month after LLA.

This finding is in accordance with Mostafa et al. (2016) ${ }^{(19)}$ who found an increase in patient's activities of daily living measured by Barthel index tool after application of exercise program in the study group more than control group. While this finding disagrees with Mathi et al. (2014) ${ }^{(43)}$ who found that quality of life was majorly affected in patients with transtibial amputation especially the domain of activity restriction followed by the domain of psychological adjustments to amputation.

As regards role limitations due to emotional problems, it was found that, the study group had higher mean scores than the 
control group and a statistical significant difference was found between the control and study groups after three months of LLA. However, there was no statistical significant difference between the two groups after one month of LLA. In contrast to this result Knezevic et al. (2015) ${ }^{(44)}$ who reported that because of the existence of numerous emotional problems such as the feeling of guilt, altered body image, anxiety and depressive behavior, patients with lower extremity amputations have numerous limitations caused by their emotional state.

The results of the current study also revealed that, the study group had higher mean scores regarding vitality (energy/fatigue) domain of quality of life than the control group and a statistical significant difference was found between the two groups at one month and three months of LLA. The rational could be the rehabilitation program included range of motion and isometric exercises for the upper and lower extremities resulting in improved muscles strength and reduced activity intolerance. This finding is supported by Nolan $(2012)^{(45)}$ who found that increased hip strength and decreased oxygen consumption during walking in patients with LLA in the study group who received hip strengthening programme.

Amputation brings significant changes in patient's life that leads to anxiety, depression, altered body image and selfconcept, all these consequences of LLA affect emotional well-being ${ }^{(31)}$. The findings of this study showed higher mean scores of emotional well-being in the study group than control group and a statistical significant difference was found between the control and study groups after one and three months of LLA. On the contrary, Senra et al. $(2011)^{(46)}$ who found that, most patients reported feelings about changes caused by the amputation in their life, such as difficulties with basic skills and daily activities, loss of independence, inferiority feelings, negative changes in their professional life and achievements; identity changes, changes in their affective or sexual life, and feeling abandoned by others.

This result may be rationalized by ventilation sessions in the rehabilitation program to allow patients in the study group to express their feelings and concerns which is considered as a part of psychological support. Furthermore, early involvement of a peer visitor to enhance the patient insight and understanding of the healing and rehabilitation process and improve coping strategies.

Regarding social functioning, the results of the present study illustrated that, mean scores of social functioning was higher in the study group than control group and a statistical significant difference was found between the control and study groups after three months of LLA. This finding is supported by Hawkins et al. (2016) ${ }^{(47)}$ who found that, increased social integration of patients after major LLA was associated with both improved function and increased quality of life scores. In addition, it is in agreement with Adegoke (2012) $)^{(48)}$ who found that the highest domain score of quality of life for patients with unilateral LLA was the social relationship.

This result could be justified by impaired physical mobility and incomplete wound healing, lack of caregivers and environmental barriers had a negative effect on social functioning of patients in the control group. However, there was no statistical significant difference between the two groups after one month of LLA that might be due to altered body image during the first month after LLA and before fitting of a prosthesis may limit social interactions because of patient's feelings of uncertainty regarding how to behave, and wanting to avoid unpleasant situations. Patients may see themselves as unfit for the society anymore after amputation due to altered body image and people in the society also may see patients as members of stigmatized group.

Concerning pain domain of quality of life, it was found that the study group had 
higher mean scores than the control group and a statistical significant difference was found between the two groups at one month and three months of LLA. According to SF36 the higher score of pain domain indicates the more functioning and well-being. It could be due to the rehabilitation program included nursing interventions for stump pain and phantom limb pain management. This finding was supported by presence of statistical significant difference in favor of the study group between both groups during the first to fourth week of postoperative follow up period regarding intensity of stump pain.

\section{Conclusion}

- The rehabilitation program had a positive effect on postoperative stump pain management and reduction of pain intensity.

- Wound healing improved significantly in patients of the study group more than patients in the control group after applying the rehabilitation program.

- Mean scores of SF-36 health domains improved significantly in patients with LLA in the study group compared to the control group after applying the rehabilitation program. Therefore, comprehensive rehabilitation interventions improve the quality of life of patients with lower limb amputation.

- Quality of life for patients with LLA improved significantly at three months compared to one month after amputation surgery.

\section{Recommendations}

Based on the finding of the current study, the following recommendations have been generated:

- The rehabilitation program should be considered as an integral part in the hospital routine care of patients with LLA.

- Continuous educational and training programs should be provided to patients with lower limb amputation on regular basis to improve their physical and psychological health and quality of life.

- Improving awareness of patients and their caregivers and counseling on post-amputation goals will enhance patients' compliance with the rehabilitation program.

- Newly employed nurses in vascular surgery department should have adequate knowledge and training before assuming independent responsibility for patient care.

- The developed handout booklet should be present in vascular units and outpatient clinics in order to be provided to patients with LLA.

- Further research for assessment of quality of life for patient with LLA after 6 months and one year is suggested. 
Table (1): Distribution of patients in both control and study groups according to their socio-demographic data $(n=50)$

\begin{tabular}{|c|c|c|c|c|c|c|}
\hline \multirow[t]{2}{*}{ Socio-demographic Data } & \multicolumn{2}{|c|}{$\begin{array}{c}\text { Control Group } \\
(\mathbf{n}=\mathbf{2 5})\end{array}$} & \multicolumn{2}{|c|}{$\begin{array}{c}\text { Study Group } \\
(\mathbf{n}=\mathbf{2 5})\end{array}$} & \multirow{2}{*}{$\begin{array}{l}\text { Test of } \\
\text { Sig. }\end{array}$} & \multirow[t]{2}{*}{$\mathbf{p}$} \\
\hline & No. & $\%$ & No. & $\%$ & & \\
\hline Age & & & & & & \\
\hline 20 years: $<30$ years & 1 & 4.0 & 2 & 8.0 & & \\
\hline 30 years: < 40 years & 1 & 4.0 & 0 & 0.0 & $\chi^{2}=$ & ${ }^{\mathrm{MC}} \mathrm{p}=$ \\
\hline 40 years: $<50$ years & 8 & 32.0 & 11 & 44.0 & 2.154 & 0.590 \\
\hline 50 years : $<60$ years & 15 & 60.0 & 12 & 48.0 & & \\
\hline Mean \pm SD. & \multicolumn{2}{|c|}{$49.28 \pm 8.38$} & \multicolumn{2}{|c|}{$47.72 \pm 9.30$} & $\mathrm{t}=0.623$ & 0.536 \\
\hline Sex & & & & & & \\
\hline Male & 16 & 64.0 & 15 & 60.0 & $\chi^{2}=$ & ${ }^{\mathrm{FE}} \mathrm{p}=$ \\
\hline Female & 9 & 36.0 & 10 & 40.0 & 0.085 & 0.771 \\
\hline \multicolumn{7}{|l|}{\begin{tabular}{|l} 
Educational Level \\
\end{tabular}} \\
\hline Illiterate & 7 & 28.0 & 5 & 20.0 & \multirow{6}{*}{$\begin{array}{c}\chi^{2}= \\
5.793\end{array}$} & \multirow{6}{*}{$\begin{array}{l}{ }_{\mathrm{p}}^{\mathrm{MC}}= \\
0.349\end{array}$} \\
\hline Read and write & 4 & 16.0 & 3 & 12.0 & & \\
\hline Primary education & 4 & 16.0 & 4 & 16.0 & & \\
\hline Preparatory education & 4 & 16.0 & 1 & 4.0 & & \\
\hline Secondary education & 1 & 4.0 & 6 & 24.0 & & \\
\hline University & 5 & 20.0 & 6 & 24.0 & & \\
\hline \multicolumn{6}{|l|}{ Marital Status } & \multirow{5}{*}{$\begin{array}{l}{ }^{\mathrm{MC}}= \\
0.637\end{array}$} \\
\hline Single & 2 & 8.0 & 2 & 8.0 & & \\
\hline Married & 21 & 84.0 & 18 & 72.0 & $\chi^{2}=$ & \\
\hline Divorced & 0 & 0.0 & 2 & 8.0 & 2.245 & \\
\hline Widow & 2 & 8.0 & 3 & 12.0 & & \\
\hline \multicolumn{5}{|l|}{ Occupation } & \multirow{5}{*}{$\begin{array}{l}\chi^{2}= \\
6.445\end{array}$} & \multirow{5}{*}{$\begin{array}{c}{ }_{\mathrm{pC}}^{\mathrm{MC}}= \\
0.086\end{array}$} \\
\hline Manual & 13 & $\mathbf{5 2 . 0}$ & 6 & 24.0 & & \\
\hline Employee & 5 & 20.0 & 11 & 44.0 & & \\
\hline Housewife & 4 & 16.0 & 7 & 28.0 & & \\
\hline Retired & 3 & 12.0 & 1 & 4.0 & & \\
\hline $\begin{array}{l}\text { Income from patient point of view } \\
\text { Enough }\end{array}$ & 10 & 40.0 & 10 & 40.0 & $\chi^{2}=$ & ${ }^{\mathrm{FE}} \mathrm{p}=$ \\
\hline Not Enough & 15 & 60.0 & 15 & 60.0 & $\begin{array}{l}\pi \\
0.0\end{array}$ & 1.000 \\
\hline
\end{tabular}


Table (2): Distribution of patients in the control and study groups according to medical data $(\mathbf{n}=\mathbf{5 0})$

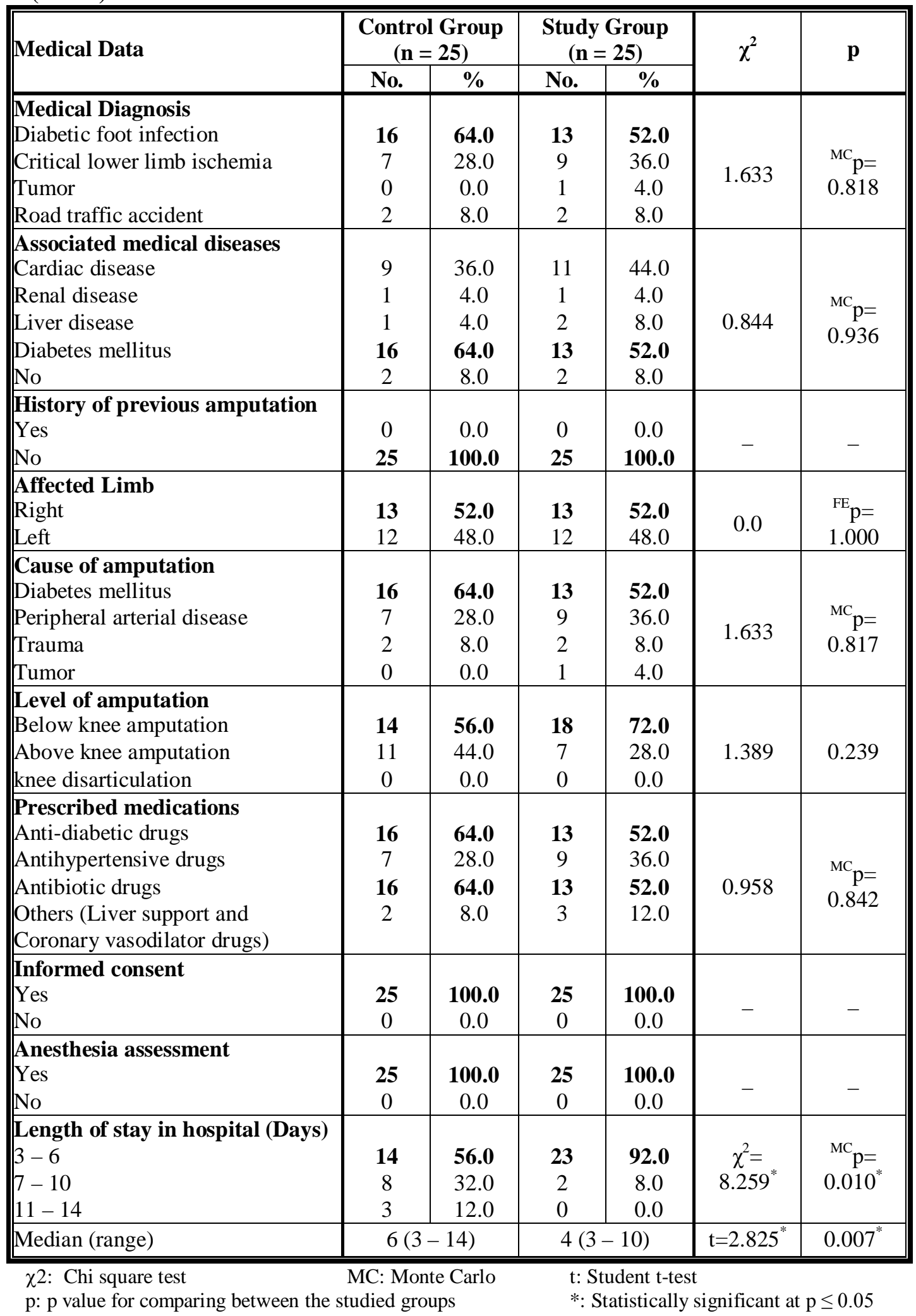


Table (3): Postoperative pain assessment of patients in the control and study groups during hospitalization and after discharge (follow up weeks) $(\mathbf{n}=50)$

\begin{tabular}{|c|c|c|c|c|c|c|c|c|c|c|c|}
\hline \multirow{3}{*}{$\mathbf{Q}$} & \multirow{3}{*}{ Pain Assessment } & \multirow{2}{*}{\multicolumn{2}{|c|}{$\begin{array}{c}\text { a. During } \\
\text { Hospitalization }\end{array}$}} & \multicolumn{8}{|c|}{ b. After Discharge (Follow up weeks) } \\
\hline & & & & \multicolumn{2}{|c|}{$1^{\text {st }}$ week } & \multicolumn{2}{|c|}{$2^{\text {nd }}$ week } & \multicolumn{2}{|c|}{$3^{\text {rd }}$ week } & \multicolumn{2}{|c|}{$4^{\text {th }}$ Week } \\
\hline & & No. & $\%$ & No. & $\%$ & No. & $\%$ & No. & $\%$ & No. & $\%$ \\
\hline \multirow{6}{*}{ 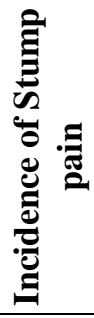 } & Control $(n=25)$ & & & & & & & & & & \\
\hline & Yes & 25 & 100.0 & 25 & 100.0 & 24 & 96.0 & 21 & 84.0 & 18 & 72.0 \\
\hline & No & 0 & 0.0 & 0 & 0.0 & 1 & 4.0 & 4 & 16.0 & 7 & 28.0 \\
\hline & $\begin{array}{l}\text { Study }(\mathbf{n}=\mathbf{2 5}) \\
\text { Yes }\end{array}$ & 25 & 100.0 & 25 & 100.0 & 22 & 88.0 & 19 & 76.0 & 15 & 60.0 \\
\hline & No & 0 & 0.0 & 0 & 0.0 & 3 & 12.0 & 6 & 24.0 & 10 & 40.0 \\
\hline & $\chi^{2}(\mathbf{p})$ & \multicolumn{2}{|c|}{-} & \multicolumn{2}{|c|}{-} & \multicolumn{2}{|c|}{$\begin{array}{c}1.087 \\
\left({ }^{\mathrm{FE}}=0.609\right)\end{array}$} & \multicolumn{2}{|c|}{$\begin{array}{c}0.500 \\
(0.480) \\
\end{array}$} & \multicolumn{2}{|c|}{$\begin{array}{c}0.802 \\
(0.370) \\
\end{array}$} \\
\hline \multirow{3}{*}{ 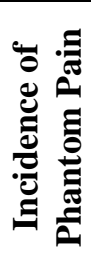 } & $\begin{array}{l}\text { Control }(\mathbf{n}=\mathbf{2 5}) \\
\text { Yes } \\
\text { No } \\
\end{array}$ & $\begin{array}{c}0 \\
25 \\
\end{array}$ & $\begin{array}{c}0.0 \\
\mathbf{1 0 0 . 0} \\
\end{array}$ & $\begin{array}{c}0 \\
25 \\
\end{array}$ & $\begin{array}{c}0.0 \\
\mathbf{1 0 0 . 0}\end{array}$ & $\begin{array}{c}0 \\
25 \\
\end{array}$ & $\begin{array}{c}0.0 \\
\mathbf{1 0 0 . 0}\end{array}$ & $\begin{array}{c}0 \\
25\end{array}$ & $\begin{array}{c}0.0 \\
\mathbf{1 0 0 . 0}\end{array}$ & $\begin{array}{c}0 \\
25 \\
\end{array}$ & $\begin{array}{c}0.0 \\
100.0\end{array}$ \\
\hline & $\begin{array}{l}\text { Study }(\mathbf{n}=\mathbf{2 5}) \\
\text { Yes } \\
\text { No }\end{array}$ & $\begin{array}{c}0 \\
25\end{array}$ & $\begin{array}{c}0.0 \\
100.0\end{array}$ & $\begin{array}{c}0 \\
25\end{array}$ & $\begin{array}{c}0.0 \\
100.0\end{array}$ & $\begin{array}{c}0 \\
25\end{array}$ & $\begin{array}{c}0.0 \\
100.0\end{array}$ & $\begin{array}{c}0 \\
25\end{array}$ & $\begin{array}{c}0.0 \\
100.0\end{array}$ & $\begin{array}{c}0 \\
25\end{array}$ & $\begin{array}{c}0.0 \\
100.0\end{array}$ \\
\hline & $\chi^{2}(p)$ & \multicolumn{2}{|c|}{-} & \multicolumn{2}{|c|}{-} & \multicolumn{2}{|c|}{-} & \multicolumn{2}{|c|}{-} & \multicolumn{2}{|c|}{-} \\
\hline & Control $(n=25)$ & & & 3 & 12 , & 2 & 125 & 2 & 142 & 2 & 167 \\
\hline & $\begin{array}{l}\text { DuIl } \\
\text { Sawing }\end{array}$ & $\begin{array}{l}2 \\
7\end{array}$ & $\begin{array}{c}8.0 \\
28.0\end{array}$ & $\begin{array}{l}3 \\
6\end{array}$ & $\begin{array}{l}12.0 \\
24.0\end{array}$ & $\begin{array}{l}3 \\
5\end{array}$ & $\begin{array}{l}12.5 \\
20.8\end{array}$ & $\begin{array}{l}3 \\
5\end{array}$ & $\begin{array}{l}14.3 \\
23.8\end{array}$ & $\begin{array}{l}3 \\
3\end{array}$ & $\begin{array}{l}10.7 \\
16.7\end{array}$ \\
\hline & Pricking & 7 & 28.0 & 8 & 32.0 & 10 & 41.6 & 9 & 42.8 & 9 & 50.0 \\
\hline & Burning & 5 & 20.0 & 4 & 16.0 & 4 & 16.7 & 3 & 14.3 & 2 & 11.1 \\
\hline & Stabbing & 2 & 8.0 & 2 & 8.0 & 1 & 4.2 & 1 & 4.8 & 1 & 5.5 \\
\hline ఫ্் & Spastic & 2 & 8.0 & 2 & 8.0 & 1 & 4.2 & 0 & 0.0 & 0 & 0.0 \\
\hline ฮี & Study $(n=25)$ & & & & & & & & & & \\
\hline 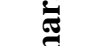 & Dull & 2 & 8.0 & 2 & 8.0 & 2 & 9.1 & 1 & 5.3 & 1 & 6.7 \\
\hline లீ & Sawing & 1 & 4.0 & 1 & 4.0 & 1 & 4.5 & 1 & 5.3 & 0 & 0.0 \\
\hline & Pricking & 10 & 40.0 & 10 & 40.0 & 10 & 45.5 & 9 & 47.4 & 9 & 60.0 \\
\hline & Burning & 6 & 24.0 & 6 & 24.0 & 6 & 27.3 & 6 & 31.5 & 5 & 33.3 \\
\hline & Stabbing & 5 & 20.0 & 5 & 20.0 & 3 & 13.6 & 2 & 10.5 & 0 & 0.0 \\
\hline & Spastic & 1 & 4.0 & 1 & 4.0 & 0 & 0.0 & 0 & 0.0 & 0 & 0.0 \\
\hline & $\chi^{2}(p)$ & $\begin{array}{r}{ }^{\mathrm{MC}}{ }_{\mathrm{p}}^{6} \\
\end{array}$ & $\begin{array}{l}03 \\
0.227) \\
\end{array}$ & ${ }^{\mathrm{MC}}{ }_{\mathrm{p}}^{5}$ & $\begin{array}{l}52 \\
.312) \\
\end{array}$ & $\left({ }^{\mathrm{MC}} 1\right.$ & $\begin{array}{l}79 \\
.419) \\
\end{array}$ & $\begin{array}{r}4 \\
{ }^{\mathrm{MC}} \mathrm{p} \\
\end{array}$ & $\begin{array}{l}31 \\
.348) \\
\end{array}$ & $\begin{array}{r}5 \\
\left({ }^{\mathrm{MC}} \mathrm{p}\right. \\
\end{array}$ & $\begin{array}{l}6 \\
.220) \\
\end{array}$ \\
\hline & Control $(n=25)$ & & & & & & & & & & \\
\hline & Continuous & 7 & 28.0 & 3 & 12.0 & 3 & 12.5 & 2 & 9.5 & 2 & 11.1 \\
\hline$\approx$ & Intermittent & 18 & 72.0 & 22 & 88.0 & 21 & 87.5 & 19 & 90.5 & 16 & 88.9 \\
\hline ש & Study $(\mathrm{n}=25)$ & & & & & & & & & & \\
\hline$\stackrel{T}{\exists}$ & Continuous & 5 & 20.0 & 2 & 8.0 & 2 & 9.1 & 2 & 10.5 & 2 & 13.3 \\
\hline$\tilde{a}$ & Intermittent & 20 & 80.0 & 23 & 92.0 & 20 & 90.9 & 17 & 89.5 & 13 & 86.7 \\
\hline & $\chi^{2}(\mathbf{p})$ & & $\begin{array}{l}39 \\
08)\end{array}$ & & & $\left({ }^{\mathrm{FE}} \mathrm{p}\right.$ & $\begin{array}{l}38 \\
.000)\end{array}$ & $\left({ }^{\mathrm{FE}}{ }_{\mathrm{p}}^{0}\right.$ & $\begin{array}{l}11 \\
.000)\end{array}$ & $\left({ }^{\mathrm{FE}}{ }_{\mathrm{p}}^{0}\right.$ & $\begin{array}{l}38 \\
000)\end{array}$ \\
\hline & Control $(n=25)$ & & & & & & & & & & \\
\hline & No pain $\quad(0)$ & 0 & 0.0 & 0 & 0.0 & 1 & 4.0 & 4 & 16.0 & 7 & 28.0 \\
\hline & Mild pain (1-3) & 5 & 20.0 & 6 & 24.0 & 7 & 28.0 & 8 & 32.0 & 6 & 24.0 \\
\hline & Moderate pain (4-6) & 10 & 40.0 & 9 & 36.0 & 11 & 44.0 & 10 & 40.0 & 9 & 36.0 \\
\hline 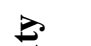 & Severe pain (7-9) & 6 & 24.0 & 8 & 32.0 & 5 & 20.0 & 3 & 12.0 & 3 & 12.0 \\
\hline "厂 & Worst possible pain(10) & 4 & 16.0 & 2 & 8.0 & 1 & 4.0 & 0 & 0.0 & 0 & 0.0 \\
\hline$\stackrel{\bar{\Xi}}{=}$ & Study $(n=25)$ & & & & & & & & & & \\
\hline.$\Xi$ & No pain $\quad(0)$ & 0 & 0.0 & 0 & 0.0 & 3 & 12.0 & 6 & 24.0 & 10 & 40.0 \\
\hline . & Mild pain (1-3) & 7 & 28.0 & 12 & 48.0 & 15 & 70.0 & 15 & 60.0 & 13 & $\mathbf{5 2 . 0}$ \\
\hline & Moderate pain (4-6) & 12 & 48.0 & 11 & 44.0 & 7 & 28.0 & 4 & 16.0 & 2 & 8.0 \\
\hline & Severe pain $(7-9)$ & 3 & 12.0 & 2 & 8.0 & 0 & 0.0 & 0 & 0.0 & 0 & 0.0 \\
\hline & Worst possible pain(10) & 3 & 12.0 & 0 & 0.0 & 0 & 0.0 & 0 & 0.0 & 0 & 0.0 \\
\hline & $\chi^{2}(p)$ SIG & & $\begin{array}{l}58 \\
92)\end{array}$ & ${ }^{\mathrm{MC}}{ }_{\mathrm{p}}^{7 .}$ & $\left.82^{*} .039^{*}\right)$ & $\begin{aligned} 1 \\
{ }^{\mathrm{MC}} \mathrm{p}\end{aligned}$ & $\begin{array}{l}68^{*} \\
\left.014^{*}\right)\end{array}$ & & $\begin{array}{l}5 \\
\left.5^{*}\right)\end{array}$ & & $\begin{array}{l}63^{*} \\
\left.2^{*}\right)\end{array}$ \\
\hline
\end{tabular}

$\chi 2$ : Chi square test, MC: Monte Carlo, FE: Fisher Exact, $\mathrm{p}$ : $\mathrm{p}$ value for comparing between studied groups, ${ }^{*}:$ Statistically significant at $\mathrm{p} \leq 0.05$ 
Table (4): Postoperative assessment of wound healing of patients in the control and study groups during hospitalization and after discharge (follow up weeks) $(n=50)$

\begin{tabular}{|c|c|c|c|c|c|c|c|c|c|c|}
\hline \multirow{4}{*}{\begin{tabular}{|l} 
Wound Healing \\
Control $(\mathbf{n}=\mathbf{2 5})$ \\
Complete healing (7-14) \\
Incomplete healing (15- \\
$22)$
\end{tabular}} & \multirow{2}{*}{\multicolumn{2}{|c|}{$\begin{array}{c}\text { a. During } \\
\text { Hospitalization } \\
\end{array}$}} & \multicolumn{8}{|c|}{ b. After Discharge (Follow up weeks) } \\
\hline & & & \multicolumn{2}{|c|}{$1^{\text {st }}$ week } & \multicolumn{2}{|c|}{$2^{\text {nd }}$ week } & \multicolumn{2}{|c|}{$3^{\text {rd }}$ week } & \multicolumn{2}{|c|}{$4^{\text {th }}$ week } \\
\hline & 20 & 80.0 & 10 & 40.0 & 13 & 52.0 & 15 & 60.0 & 16 & 64.0 \\
\hline & 5 & 20.0 & 15 & 60.0 & 12 & 48.0 & 10 & 40.0 & 9 & 36.0 \\
\hline $\begin{array}{l}\text { Min. - Max. } \\
\text { Mean } \pm \text { SD. }\end{array}$ & \multicolumn{2}{|c|}{$\begin{array}{c}9.0-19.0 \\
13.60 \pm 2.50\end{array}$} & \multicolumn{2}{|c|}{$\begin{array}{c}7.0-20.0 \\
15.08 \pm 4.09\end{array}$} & \multicolumn{2}{|c|}{$\begin{array}{c}8.0-20.0 \\
14.16 \pm 4.55\end{array}$} & \multicolumn{2}{|c|}{$\begin{array}{c}10.0-18.0 \\
14.04 \pm 2.34\end{array}$} & \multicolumn{2}{|c|}{$\begin{array}{c}10.0-18.0 \\
14.16 \pm 2.51\end{array}$} \\
\hline $\begin{array}{l}\text { Study }(\mathbf{n}=\mathbf{2 5}) \\
\text { Complete healing (7-14) } \\
\text { Incomplete healing (15- } \\
\text { 22) }\end{array}$ & $\begin{array}{c}23 \\
2\end{array}$ & $\begin{array}{c}92.0 \\
8.0\end{array}$ & $\begin{array}{l}14 \\
11\end{array}$ & $\begin{array}{l}\mathbf{5 6 . 0} \\
44.0\end{array}$ & $\begin{array}{c}20 \\
5\end{array}$ & $\begin{array}{l}80.0 \\
20.0\end{array}$ & $\begin{array}{c}22 \\
3\end{array}$ & $\begin{array}{l}\mathbf{8 8 . 0} \\
12.0\end{array}$ & $\begin{array}{c}23 \\
2\end{array}$ & $\begin{array}{c}92.0 \\
8.0\end{array}$ \\
\hline $\begin{array}{l}\text { Min. - Max. } \\
\text { Mean } \pm \text { SD. }\end{array}$ & \multicolumn{2}{|c|}{$\begin{array}{c}11.0-16.0 \\
12.60 \pm 1.47\end{array}$} & \multicolumn{2}{|c|}{$\begin{array}{c}7.0-18.0 \\
13.04 \pm 4.08\end{array}$} & \multicolumn{2}{|c|}{$\begin{array}{c}7.0-20.0 \\
12.04 \pm 4.0\end{array}$} & \multicolumn{2}{|c|}{$\begin{array}{c}10.0-17.0 \\
11.88 \pm 1.94\end{array}$} & \multicolumn{2}{|c|}{$\begin{array}{c}10.0-18.0 \\
11.60 \pm 2.06\end{array}$} \\
\hline$\chi^{2}(\mathbf{p})$ & \multicolumn{2}{|c|}{$\begin{array}{c}1.495 \\
\left({ }^{\mathrm{FE}} \mathrm{p}=0.417\right)\end{array}$} & \multicolumn{2}{|c|}{$\begin{array}{c}1.282 \\
(0.258)\end{array}$} & \multicolumn{2}{|c|}{$\begin{array}{l}4.367^{*} \\
\left(0.037^{*}\right)\end{array}$} & \multicolumn{2}{|c|}{$\begin{array}{c}5.094^{*} \\
\left(0.024^{*}\right)\end{array}$} & \multicolumn{2}{|c|}{$\begin{array}{c}5.711^{*} \\
\left(0.017^{*}\right)\end{array}$} \\
\hline
\end{tabular}

$\chi 2$ : Chi square test

FE: Fisher Exact

$\mathrm{p}$ : $\mathrm{p}$ value for comparing between the studied groups

*: Statistically significant at $\mathrm{p} \leq 0.05$

Table (5): Comparison between the Control and Study Groups according to Quality of Life Domains $(\mathbf{n}=\mathbf{5 0})$

\begin{tabular}{|c|c|c|c|c|c|}
\hline Quality of Life Domains & $\begin{array}{c}\text { Total Score of } \\
\text { QOL } \\
\end{array}$ & $\begin{array}{l}\text { Control } \\
(\mathbf{n}=25)\end{array}$ & $\begin{array}{c}\text { Study } \\
(n=25)\end{array}$ & $\mathbf{t}$ & $\mathbf{p}_{0}$ \\
\hline \multirow{3}{*}{ Physical functioning } & $\begin{array}{l}\mathbf{1}^{\text {st }} \text { Month } \\
\text { Mean } \pm \text { SD. }\end{array}$ & $7.60 \pm 10.72$ & $13.80 \pm 7.81$ & $2.338^{*}$ & $0.024 *$ \\
\hline & $\begin{array}{l}3^{\text {rd }} \text { Month } \\
\text { Mean } \pm \text { SD }\end{array}$ & $17.40 \pm 12.68$ & $30.0 \pm 11.37$ & $3.701 *$ & $0.001 *$ \\
\hline & $t(p)$ & $10.487^{*}\left(<0.001^{*}\right)$ & $9.448^{*}\left(<0.001^{*}\right)$ & & \\
\hline \multirow{3}{*}{$\begin{array}{l}\text { Role limitations due to } \\
\text { physical health }\end{array}$} & $\begin{array}{l}1^{\text {st }} \text { Month } \\
\text { Mean } \pm \text { SD. }\end{array}$ & $11.0 \pm 12.67$ & $19.0 \pm 16.58$ & 1.917 & 0.061 \\
\hline & $\begin{array}{l}3^{\text {rd }} \text { Month } \\
\text { Mean } \pm \text { SD. }\end{array}$ & $13.0 \pm 16.33$ & $45.0 \pm 16.14$ & $6.969 *$ & $<0.001 *$ \\
\hline & $\mathbf{t}(\mathbf{p})$ & $0.492(0.627)$ & $6.586^{*}\left(<0.001^{*}\right)$ & & \\
\hline \multirow{3}{*}{$\begin{array}{l}\text { Role limitations due to } \\
\text { emotional problems }\end{array}$} & $\begin{array}{l}\mathbf{1}^{\text {st }} \text { Month } \\
\text { Mean } \pm \text { SD. }\end{array}$ & $42.67 \pm 22.61$ & $44.0 \pm 30.0$ & 0.177 & 0.860 \\
\hline & $\begin{array}{l}3^{\text {rd }} \text { Month } \\
\text { Mean } \pm \text { SD. }\end{array}$ & $44.0 \pm 24.94$ & $84.04 \pm 16.96$ & $6.638^{*}$ & $<0.001 *$ \\
\hline & $\mathbf{t}(\mathbf{p})$ & $0.189(0.852)$ & $5.207^{*}\left(<0.001^{*}\right)$ & & \\
\hline \multirow{3}{*}{ Energy/fatigue } & $\begin{array}{l}\mathbf{1}^{\text {st }} \text { Month } \\
\text { Mean } \pm \text { SD. }\end{array}$ & $14.40 \pm 8.58$ & $20.20 \pm 5.86$ & $2.792 *$ & $0.008^{*}$ \\
\hline & $\begin{array}{l}3^{\text {rd }} \text { Month } \\
\text { Mean } \pm \text { SD. }\end{array}$ & $23.40 \pm 8.26$ & $34.0 \pm 7.77$ & $4.674 *$ & $<0.001 *$ \\
\hline & $\mathbf{t}(\mathbf{p})$ & $8.332^{*}\left(<0.001^{*}\right)$ & $10.887^{* \prime}\left(<0.001^{*}\right)$ & & \\
\hline
\end{tabular}

t0: Student t-test

t: Paired t-test

*: Statistically significant at $\mathrm{p} \leq 0.05$

$\mathrm{p} 0$ : $\mathrm{p}$ value for comparing between the studied groups

$\mathrm{p}$ : $\mathrm{p}$ value for comparing between the studied periods in each group 
Table (5): Continued

\begin{tabular}{|c|c|c|c|c|c|}
\hline Quality of Life Domains & $\begin{array}{c}\text { Total Score of } \\
\text { QOL }\end{array}$ & $\begin{array}{l}\text { Control } \\
(\mathrm{n}=25)\end{array}$ & $\begin{array}{c}\text { Study } \\
(\mathrm{n}=\mathbf{2 5})\end{array}$ & $\mathbf{t}$ & $\mathbf{p}_{0}$ \\
\hline \multirow{2}{*}{ Emotional well-being } & $\begin{array}{c}\mathbf{1}^{\text {st }} \text { Month } \\
\text { Mean } \pm \text { SD. }\end{array}$ & $28.80 \pm 10.13$ & $34.88 \pm 7.26$ & $2.439^{*}$ & $0.019 *$ \\
\hline & $\begin{array}{c}3^{\text {rd }} \text { Month } \\
\text { Mean } \pm \text { SD. }\end{array}$ & $33.12 \pm 7.17$ & $37.92 \pm 6.54$ & $2.473^{*}$ & $0.017 *$ \\
\hline & $\mathbf{t}(\mathbf{p})$ & $1.576(0.158)$ & $2.128^{*}\left(0.044^{*}\right)$ & & \\
\hline \multirow{3}{*}{ Social functioning } & $\begin{array}{c}\mathbf{1}^{\text {st }} \text { Month } \\
\text { Mean } \pm \text { SD. }\end{array}$ & $18.0 \pm 15.34$ & $22.0 \pm 9.74$ & 1.101 & 0.277 \\
\hline & $\begin{array}{c}3^{\text {rd }} \text { Month } \\
\text { Mean } \pm \text { SD. }\end{array}$ & $25.0 \pm 11.41$ & $56.50 \pm 14.03$ & $8.709^{*}$ & $<0.001^{*}$ \\
\hline & $t(p)$ & $1.864(0.075)$ & $15.693^{*}\left(<0.001^{*}\right)$ & & \\
\hline \multirow{3}{*}{ Pain } & $\begin{array}{c}\mathbf{1}^{\text {st }} \text { Month } \\
\text { Mean } \pm \text { SD. }\end{array}$ & $23.90 \pm 13.86$ & $34.40 \pm 10.47$ & $3.022 *$ & $0.004^{*}$ \\
\hline & $\begin{array}{c}\mathbf{3}^{\text {rd }} \text { week } \\
\text { Mean } \pm \text { SD. }\end{array}$ & $47.80 \pm 12.77$ & $66.80 \pm 13.87$ & $5.037 *$ & $<0.001 *$ \\
\hline & $\mathbf{t}(\mathbf{p})$ & $8.299^{*}\left(<0.001^{*}\right)$ & $16.265^{*}\left(<0.001^{*}\right)$ & & \\
\hline \multirow{3}{*}{ General health } & $\begin{array}{c}\mathbf{1}^{\text {st }} \text { Month } \\
\text { Mean } \pm \text { SD. }\end{array}$ & $23.80 \pm 12.85$ & $35.20 \pm 10.94$ & $3.377^{*}$ & $<0.001 *$ \\
\hline & $\begin{array}{l}3^{\text {rd }} \text { Month } \\
\text { Mean } \pm \text { SD. }\end{array}$ & $25.60 \pm 11.21$ & $45.20 \pm 14.03$ & $5.457 *$ & $<0.001^{*}$ \\
\hline & $\mathbf{t}(\mathbf{p})$ & $0.799(0.432)$ & $5.695^{*}\left(<0.001^{*}\right)$ & & \\
\hline \multirow{3}{*}{$\begin{array}{l}\text { Physical component } \\
\text { summary (Physical } \\
\text { health) }\end{array}$} & $\begin{array}{l}\mathbf{1}^{\text {st }} \text { month } \\
\text { Mean } \pm \text { SD. }\end{array}$ & $16.08 \pm 8.29$ & $25.60 \pm 9.76$ & $3.720 *$ & $0.001^{*}$ \\
\hline & $\begin{array}{c}3^{\text {rd }} \text { month } \\
\text { Mean } \pm \text { SD. }\end{array}$ & $25.95 \pm 10.34$ & $46.75 \pm 11.58$ & $6.697 *$ & $<0.001^{*}$ \\
\hline & $t(p)$ & $6.837^{*}\left(<0.001^{*}\right)$ & $12.249^{*}\left(<0.001^{*}\right)$ & & \\
\hline \multirow{3}{*}{$\begin{array}{l}\text { Mental component } \\
\text { summary } \\
\text { (Mental health) }\end{array}$} & $\begin{array}{c}\mathbf{1}^{\text {st }} \text { month } \\
\text { Mean } \pm \text { SD. }\end{array}$ & $23.97 \pm 10.27$ & $30.26 \pm 7.80$ & $2.437^{*}$ & $0.019 *$ \\
\hline & $\begin{array}{c}\mathbf{3}^{\text {rd }} \text { month } \\
\text { Mean } \pm S D\end{array}$ & $31.38 \pm 9.05$ & $53.12 \pm 8.39$ & $8.808^{*}$ & $<0.001^{*}$ \\
\hline & $t(p)$ & $2.977^{*}\left(0.007^{*}\right)$ & $11.307^{*}\left(<0.001^{*}\right)$ & & \\
\hline \multirow{3}{*}{ Overall } & $\begin{array}{c}\mathbf{1}^{\text {st }} \text { month } \\
\text { Mean } \pm \text { SD. }\end{array}$ & $22.44 \pm 5.81$ & $26.72 \pm 7.87$ & $2.185^{*}$ & $0.034^{*}$ \\
\hline & $\begin{array}{c}3^{\text {rd }} \text { month } \\
\text { Mean } \pm \text { SD. }\end{array}$ & $27.37 \pm 8.84$ & $47.05 \pm 9.18$ & $7.720 *$ & $<0.001 *$ \\
\hline & $\mathbf{t}(\mathbf{p})$ & $3.450^{*}\left(0.002^{*}\right)$ & $12.306^{*}\left(<0.001^{*}\right)$ & & \\
\hline
\end{tabular}

t0: Student t-test

t: Paired t-test

*: Statistically significant at $\mathrm{p} \leq 0.05$

$\mathrm{p} 0$ : $\mathrm{p}$ value for comparing between the studied groups

$\mathrm{p}$ : $\mathrm{p}$ value for comparing between the studied periods in each group 


\section{References}

1. Cuff RF, Simmons JM. The management of lower extremity amputations. In: Cameron JL, Cameron Am. Current surgical therapy. $12^{\text {th }}$ ed. Canada: Elsevier, 2017; 1110.

2. Murwanashyaka E, Ssebuufu R, Kyamanywa P. Prevalence, indications, levels and outcome limb amputations at University Teaching Hospital-Butare in Rwanda. East and Central African Journal of Surgery, 2013; 18 (2): 103.

3. Fortington L. Enabling the elderly person with lower limb amputation through surgery, rehabilitation and long term care. Published Doctoral Thesis. University of Groningen, Netherlands; 2013.

4. Ajibade A, Akinniyi OT, Okoye CS. Indications and complications of major limb amputations in Kano, Nigeria. Chana Medical Journal, 2013; 47(4): 185.

5. Fredericks JP. Description and evaluation rehabilitation programme for persons with lower limb amputations at Elangeni, Paarl, South Africa. Published Master Thesis. University of Stellenbosch, South Africa; 2012.

6. Bianchi C, ABou-Zamzam AM. Lower extremity amputation: general considerations. In: Cronenwett JL, Johnston KW. Rutherford's vascular surgery. $8^{\text {th }}$ ed. China: Elsevier Saunders, 2014; 1836.

7. Limb Loss Task Force, Amputee Coalition. Roadmap for stimulating limb loss research and improving care: recommendations from the 2015 Limb Loss Task Force. Knoxville, Tennessee; 2016. Available at: http://www.amputee-

coalition.org/wpcontent/uploads/2016

/01/roadmap-for-stimulation-limb-loss-

research-and-improving-care201511tf.x18949.pdf.

8. Shalaby SY, Dardik A. Comparison of diabetic foot amputation in Egypt with the United States. In: Dardik A. Vascular surgery a global perspective. Switzerland: Springer International Publishing, 2017; 127.

9. Rosien LN, Hendriks SH, Kleefstra N, Bilo HJ, Landman JW. Nationwide diabetes-related lower extremity amputation rates in secondary care treated patients with diabetes in the Netherlands (DUDE-7). Journal of Diabetes and Its Complications, 2017; 31: 675.

10. Jones WS, Subherwal S, Peterson ED. Temporal trends and geographic variation of lower extremity amputation in patients with peripheral artery disease. Journal of the American College of Cardiology. 2012, 60(21): 2230.

11. Mohammed S, Shebl AM. Quality of life among Egyptian patients with upper and lower limb amputation: sex differences. Advances in Medicine. 2014, 2014:1.

12. Sinha R. Adjustments to amputation and artificial limb, and quality of life in lower limb amputees. Published Doctoral Thesis. Faculty of Medical Sciences, University of Groningen; 2013. Available at: https://www.rug.nl/research/portal/files/238861 4/Chapter1.pdf.

13. Hale C. Physiotherapy of people with major amputation. In: Porter S. Tidy's physiotherapy. $15^{\text {th }}$ ed. China: El Sevier, 2013; 458.

14. Durmus D, Safaz I, Adiguzel E, Uran A, et al. Psychiatric symptoms in male traumatic lower limb amputees: associations with neuropathic pain, locomotor capabilities, and perception of body image. Journal of Mood Disorders. 2015; 5(4): 165.

15. Chinomso UN, Foluso O. Relief of residual limb pain with massage therapy: A case study. International Journal of Research in Applied Natural and Social Sciences, 2014; 2(2): 111.

16. Lavelle DG. Amputations of the lower extremity. In: Azar FM, Beaty JH, Canale ST. Campbell's operative orthopaedics. $13^{\text {th }} \mathrm{ed}$, Canada: Elsevier, 2017; 674.

17. Ida K, Neven K, Ognjen Z, et al. Rehabilitation of lower limb amputees. Periodicum Biologorum Journal, 2015; 17(1): 147-52.

18. Hinkle JL, Cheever KH. Brunner \& Suddarth's textbook of medical-surgical nursing. $14^{\text {th }}$ ed. Philadelphia: Lippincott Williams \& Wilkins, 2017; 2098.

19. Mostafa NM, Mohamed ZA, Rashad SM. Effect of exercise program on functional ability of patients with lower limb amputation. IOSR Journal of Nursing and Health Science, 2016; 5(1): 1,6 .

20. Ramos V. The psychological and physical rehabilitation of amputees. Puplished Senior Honors Thesis. Liberty University, 2016.

21. Toy PC. General principles of amputations. In: Canale ST, Beaty JH. Campbell's operative orthopaedics. $13^{\text {th }}$ ed, Canada: Elsevier, 2017; 635.

22. Fathy E. The effect of clinical pathway implementation on healing of post lower limb amputation for diabetic patients. Unpublished Doctoral Thesis. Faculty of Nursing, Alexandria University; 2014.

23. Wewers M.E. \& Lowe N.K. A critical review of visual analogue scales in the measurement of clinical phenomena. Research in Nursing and Health, 1990; 13: 227-36.

24. Ware JE, Sherbourne CD. The MOS 36-item short-form health survey (SF-36): I. conceptual framework and item selection. Medical Care, 1992; 30: 473-83.

25. Ware JE. SF-36 health survey update. In: Maruish M. The use of psychological testing for treatment planning and outcome assessment, Volume 3 Instruments for adults. $3^{\text {rd }}$ ed. New Jersey: Lawrence Erlbaum Associates, 2004; 693-718. 
26. Department of Veterans Affairs, Department of Defense. VA/DoD clinical practice guideline for rehabilitation of lower limb amputation. 2017. Available at: https://www.healthquality.va.gov/guidelines/Re hab/amp/ampv652.pdf.

27. Wamsley C. Pre- and post-operative care readiness for fitting. In: Murphy D. Fundamentals of amputation care and prosthetics. United States of America: Domes medical publishing LLC, 2014; 23, 25.

28. Virani A, Werunga J, Ewashen C, Green $\mathrm{T}$. Caring for patients with limb amputation. Nursing Standard. 2015; 30(6): 51-2.

29. International Committee of the Red Cross. Exercises for lower-limb amputees: gait training. 2008. Available at: https://ar.scribd.com/document/22099383/Exerc ises-for-lower-limb-amputees-gait-training.

30. Price B. Moffatt B, Crofts D. Managing patients following a lower limb amputation. Journal of Community Nursing. 2015; 29(3): 26-33.

31. Coffey L. Goals, adaptive self-regulation, and psychosocial adjustment to lower limb amputation: A longitudinal study. Published Doctoral Thesis. Dublin City University, 2012; 6.

32. He KK, Yap S, Joo LY. Handbook of rehabilitation medicine. Singapora: World Scientific Puplishing Co, 2017; 84.

33. Sansosti LE, Crowell A, Choi ET, Meyr AJ. Rate of and factors associated with ambulation after unilateral major lower-limb amputation at an Urban US Tertiary-Care Hospital with a multidisciplinary limb salvage team. Journal of the American Podiatric Medical Association, 2017; 107(5): 358.

34. El Sebaee HA, Mohamed LA. Stressors and positive coping strategies among patients with new limb amputation. Journal of American Science, 2011; 7(9): 729.

35. Rollands R, Unnikrishnan EP, Parambil SM. Epidemiology of major limb amputations: a cross sectional study from a South Indian tertiary care hospital. International Surgery Journal, 2017; 4(5): 1644.

36. Al-Thani H, Sathian B, El-Menyar A. Assessment of healthcare costs of amputation and prosthesis for upper and lower extremities in a Qatari healthcare institution: a retrospective cohort study. BMJ Open, 2019; 9:1.

37. Frederiks JP, Visagie S. The rehabilitation programme and functional outcomes of persons with lower limb amputations at a primary level rehabilitation centre. South African Journal of Occupational Therapy, 2013; 43(3): 21.

38. Fieldsen D, Wood S. Dealing with phantom limb pain after amputation. Nursing Times 2011; 107(1): 19-22.

39. Horne CE. Complementary pain intervention pilot study in the acute hospitalization phase after lower extremity amputation surgery.
Published doctoral thesis. The Faculty of the College of Nursing, East Carolina University, 2014.

40. Webster JB. Lower limb amputation care across the active duty military and veteran populations. Phys Med Rehabil Clin N Am, 2019; 30: 89109.

41. Hisam A, Ashraf F, Rana MN, Waqar Y, Karim $S$, Irfan F. Health related quality of life in patients with single lower limb amputation. J Coll Physicians Surg Pak, 2016; 26(10): 854.

42. AlSofyani MA, AlHarthi AS, Farahat FM, Abuznadah WT. Impact of rehabilitation programs on dependency and functional performance of patients with major lower limb amputations. Saudi Med J, 2016; 37(10): 1109.

43. Mathi E, Savla D, Sreeraj SR, Mishra S. Quality of life in transtibial amputees: an exploratory study using TAPES-R questionnaire. International Journal of Health Sciences and Research, 2014; 4(7): 166.

44. Knezevic A, et al. Assessment of quality of life in patients after lower limb amputation. Med Pregl; 2015; 3(4): 106.

45. Nolan L. A training programme to improve hip strength in persons with lower limb amputation. J Rehabil Med, 2012; 44: 241.

46. Senra H, Oliveira RA, Leal I, Vieira C. Beyond the body image: a qualitative study on how adults experience lower limb amputation. Clinical Rehabilitation, 2011; 26(2): 180-191.

47. Hawkins AT, et al. The Effect of social integration on outcomes after major lower extremity amputation. J Vasc Surg, 2016; 63(1): 154.

48. Adegoke BA, Kehinde AO, Akosile CO, Oyeyemi AL. Quality of life of Nigerians with unilateral lower limb amputation. Asia Pacific Disability Rehabilitation Journal, 2012; 23(4): 81. 